\title{
Cannabis related side effects in otolaryngology: a scoping review
}

Jobanjit S. Phulka, Joel W. Howlett ${ }^{*}$ (D) and Amanda Hu

\begin{abstract}
Background: Cannabis has been rapidly legalized in North America; however, limited evidence exists around its side effects. Health Canada defines side effect as a harmful and unintended response to a health product. Given drug safety concerns, this study's purpose was to review the unintended side effects of cannabis in otolaryngology.

Methods: The Preferred Reporting Items For Systematic Reviews and Meta-analysis extension for Scoping Reviews (PRISMA-SCR) protocol was used to conduct a scoping review of the MEDLINE, EMBASE, CINAHL, and CENTRAL databases. (PROSPERO: CRD42020153022). English studies in adults were included from inception to the end of 2019. In-vitro, animal, and studies with $n<5$ were excluded. Primary outcome was defined as unintended side effects (defined as any Otolaryngology symptom or diagnosis) following cannabis use. Oxford Centre for Evidence-Based Medicine: Levels of Evidence and risk of bias using the Risk of Bias in randomized trials (RoB 2) and Risk of Bias in NonRandomized Studies of Interventions (ROBINS-I) tools were assessed.. Two authors independently reviewed all studies; the senior author settled any discrepancies.

Results: Five hundred and twenty-one studies were screened; 48 studies were analysed. Subspecialties comprised: Head and Neck (32), Otology (8), Rhinology (5), Airway (5), Laryngology (1). Cannabis use was associated with unintended tinnitus, vertigo, hearing loss, infection, malignancy, sinusitis, allergic rhinitis, thyroid dysfunction, and dyspnea. About half (54.1\%) of studies showed increased side effects, or no change in symptoms following cannabis use. Oxford Levels of Evidence was 2-4 with substantial heterogeneity. Risk of bias assessment with RoB2 was low to high and ROBINS-1 was moderate to critical.

Conclusion: This was the first comprehensive scoping review of unintended side effects of cannabis in Otolaryngology. The current literature is limited and lacks high-quality research Future randomized studies are needed to focus on therapeutic effects of cannabis in otolaryngology. Substantial work remains to guide clinicians to suggest safe, evidence-based choices for cannabis use.
\end{abstract}

Keywords: Head and neck, Voice, Hearing loss, Sinusitis, Cannabis, Adverse effects, Scoping review

\section{Introduction}

Cannabis is one of the most commonly used drugs in North America. Nearly half of the American population has used cannabis at least once in their lifetime,

\footnotetext{
*Correspondence: joel.howlett@alumni.ubc.ca
}

Division of Otolaryngology - Head and Neck Surgery, Department

of Surgery, 4th Floor, Gordon and Leslie Diamond Health Care Center, University of British Columbia, 2775 Laurel Street, Vancouver, BC V5Z1M9,

Canada with approximately $9 \%$ being current users [1]. Evolving societal perception has rapidly driven the legalization of cannabis, which has been structured to regulate it's production and sales, while promoting safe consumption [2]. Legalization has led to a perceived reduction in harm, which has been associated with an increased prevalence of cannabis consumption from 2002 to 2014 [2]. Evidence based research has followed this movement, yet a paucity of data concerning the side effects of this drug remains. original author(s) and the source, provide a link to the Creative Commons licence, and indicate if changes were made. The images or other third party material in this article are included in the article's Creative Commons licence, unless indicated otherwise in a credit line to the material. If material is not included in the article's Creative Commons licence and your intended use is not permitted by statutory regulation or exceeds the permitted use, you will need to obtain permission directly from the copyright holder. To view a copy of this licence, visit http://creativecommons.org/licenses/by/4.0/. The Creative Commons Public Domain Dedication waiver (http://creativeco mmons.org/publicdomain/zero/1.0/) applies to the data made available in this article, unless otherwise stated in a credit line to the data. 
Cannabis is derived from a flowering plant. There are three main forms of cannabis, based on the part of the plant that the drug is produced from: marijuana, hashih, and hash oil [3]. Marijuana is the least potent form and manufactured from the dried flowers and leaves. Hashish is manufactured from the resin or secreted gum of the plant. Hash oil is the most potent and manufactured from the thick oil obtained from hashish [4]. There are three routes of delivery of this drug: oral, dermal, and inhaled. Smoking the drug via the inhaled route is the most popular due to the quick onset of action [4].

Health Canada defines a side effect as "a harmful and unintended response to a health product" [5]. Pharmacists distinguish the term "side effect" from "adverse event" [6]. The latter is an undesired occurrence that results from taking a medication correctly. Side effect occurs when the medication is administered regardless of the dose. Side effect is the more accurate term for this study since the dosage of cannabis was not reliable, especially before its' legalization. A review from the New England Journal of Medicine reported adverse health effects of cannabis to be as high as 50\% [7]. This list included: addiction, abnormal brain development, progression to use of other drugs, schizophrenia, depression, anxiety, chronic bronchitis, and lung cancer. Health Canada recognizes the importance of side effects and encourages the reporting of side effects on their website with a special section for cannabis products [8]. The aforementioned list focused on psychiatry and respirology side effects of cannabis. Acute side effects of cannabis in otolaryngology may include type 1 hypersensitivity reactions, cough, rhinosinusitis, laryngopharyngitis, xerostomia, and altered neurotologic function. Chronic usage may result in periodontal disease, voice changes, impaired regulation of cell cycle, apoptosis, and cellular migration, potentially increasing the risk of head and neck malignancy [9]. Prior reviews have investigated cannabis use concerning Otolaryngology, but have been limited to the oncology and laryngology literature $[4,10]$. The purpose of this scoping review wass to understand the safety profile of cannabis and how drug use in adults has the potential for unintended side effects related to otolaryngology pathologies. The intention is to be comprehensive throughout all subspecialties of Otolaryngology, and to provide clinicians with knowledge to help patients to make safe, evidencebased choices around the use of cannabis.

\section{Methods}

This scoping review was carried out according to a review protocol that has been published in the Prospective Register of Systematic Reviews (PROSPERO Registration number: CRD42020153022). A systematic review was the initial intention for this study, but the heterogeneity of the literature and lack of high-quality evidence precluded this, and therefore a scoping review was more appropriate. The reporting of this scoping review was conducted in accordance with the Preferred Reporting Items For Systematic Reviews and Metaanalysis extension for Scoping Reviews (PRISMAScR) statement [11]. The quality of the literature was assessed with the Oxford Centre for Evidence-Based Medicine: Levels of Evidence [12].

\section{Data sources and search strategy}

A literature search was performed in electronic databases, including MEDLINE, EMBASE, CINAHL, and CENTRAL databases of the Cochrane Library from inception through October 1, 2019. The search strategy was developed with assistance from a medical librarian. Search functions were designed to incorporate two subsections by [AND] Boolean operators. Subsections contained MeSH and field-designated search terms for otolaryngology related diseases and for cannabis. A cannabis search hedge was employed to identify both formal and informal terms for cannabis in the literature [13]. Additionally, reference lists from previously published reviews were screened for articles not identified in the initial search. Detailed search strategies are reported in "Appendix A".

\section{Study selection}

All articles identified via the literature search were exported to Covidence (Veritas Health Innovation Ltd., Melbourne, Australia), a systematic review management software. Study selection was independently undertaken by two authors (J.P.\& J.H.) with discrepancies being resolved by consensus with the senior author (A.H.). Inclusion criteria included: (1) English language study, (2) adult population ( $\geq 18$ years old), (3) sample size $\geq 5$, (4) clinical study, (5) study subjects report use or were exposed to cannabis, and (6) report of otolaryngology related side effects (symptom or diagnosis) following cannabis use that were unintended. Of note, no pediatric studies were included in this scoping review. Most legislation for legal cannabis prohibits consumption in the pediatric population. The exclusion criteria included: (1) in-vitro or animal study and (2) inappropriate study or publication type (e.g. systematic review, literature review, or book chapter). Additionally, side effects involving the lower airways were excluded as this is generally considered outside of the scope of an Otolaryngologist, and primarily managed by Pulmonology Medicine. The areas of wound healing, analgesia and pain were excluded as they are non-specific to 
the head and neck. Lastly, the purpose of this scoping review was not to evaluate the therapeutic indications of cannabis in otolaryngology, but to evaluate the unintended otolaryngologic side effects of consuming cannabis recreationally or medically.

\section{Main outcome}

This study used Health Canada's definition of side effect [5]. The primary study concept was to examine unintended Otolaryngology related side effects following any level of cannabis exposure. Otolaryngology related side effects were defined as a pathologic diagnosis or symptom commonly treated by an Otolaryngologist.

\section{Data extraction}

Data extraction was conducted by a single author (J.P.) and reviewed by a second author (J.H.). Information extracted from each study included: title, first author, year of publication, study design and objectives, characteristics of study participants, intervention(s) and control(s), tobacco use, cannabis consumption and amount (e.g. joint year), primary study outcomes and main findings including otolaryngology related side effects after cannabis exposure.

\section{Evaluation of risk of bias}

Risk of bias assessment was conducted independently by two study authors (J.P.\& J.H.) using the Risk of Bias in randomized trials (RoB 2) and Risk of Bias in Non-Randomized Studies of Interventions (ROBINS-I) tools [14, 15]. The senior author (AH) settled any discrepancies.

\section{Results}

\section{Study selection}

A study flow diagram is shown in Fig. 1. The comprehensive database search identified 614 articles and 12 additional articles were identified through the hand searching of reference lists. After removal of duplicates, 521 abstracts were screened. Full-text review of 117 articles excluded a further 69 articles. In total, 48 articles met the inclusion criteria and underwent data extraction and analysis.

\section{Characteristics of included studies}

Detailed characteristics of the 48 studies included are described in Table 1. Among the included studies there were: 17 case-control studies, 14 cross-sectional studies, 6 cohort studies, 6 case series, and 5 randomized controlled trials (RCTs). There was significant heterogeneity in study design, objective, and strength of the evidence reported. Quality of the literature ranged from level two to four, as shown in Table 1. The sample size of participants in the included studies ranged from
5 to 29,195 . The amount of cannabis consumption was reported by the majority of studies (33). A total of 12 studies expressed cannabis consumption in joint-years, defined as the number of joints smoked per day, multiplied by the duration in years. This ranged from $<1$ to 62.1 joint-years. Studies not expressing cannabis consumption in joint-years either failed to report the amount of cannabis use or instead reported frequency or weight of cannabis consumption. A large proportion of participants in the included studies also reported tobacco use in addition to cannabis consumption, ranging from 0 to $89.1 \%$. All included articles reported on at least one otolaryngology related side effect following cannabis exposure.

\section{Subspecialty synthesis}

A wide variety of otolaryngology subspecialties were represented (Fig. 2). Below is a synthesis of the results and highlights of themes, trends, and gaps categorized by subspecialty.

\section{Head and neck}

The most studies were published in head and neck $(H \& N)(n=32)$, with the majority evaluating cannabis' association with H\&N malignancy $(\mathrm{n}=24)[16-20,25$, $26,28-30,32,37,39,40,42,45,46,49,50,55,59-62]$. Eleven studies reported an increased risk of $H \& N$ malignancy following cannabis exposure. Conversely, 12 studies reported no change in risk and two studied reported a decreased risk of H\&N cancer following cannabis use. In general, cannabis exposure (via smoking) was associated with increased risk of oropharyngeal carcinoma [30, 42, 59], while oral cavity carcinoma risk was unaffected [32, $39,40,42]$. This effect appeared to be dose dependant in nature, where low-moderate use had a reduced effect on carcinoma development [37, 42], while higher lifetime use associated a greater risk of malignancy [30, 60].

Eight studies described an association between cannabis and $H \& N$ infection, for example, human papilloma virus (HPV) and aspergillus [24, 26, 27, 30, 35, 36, $45,59]$. Three studies reported a positive association between HPV and cannabis exposure [24, 30, 59], while three studied reported no association [26, 35, 45]. Four studies identified the effect of cannabis use on thyroid function [21, 34, 41, 47]. One study reported no association [21] and three study showed a significant association [34, 41, 47].

Overall, forming a firm conclusion on the effects of cannabis in H\&N may be challenging, as many studies reported opposing findings. For example, Berthiller et al. described no association between cannabis use and the risk of H\&N cancer [19]. However, Zhang et al. 


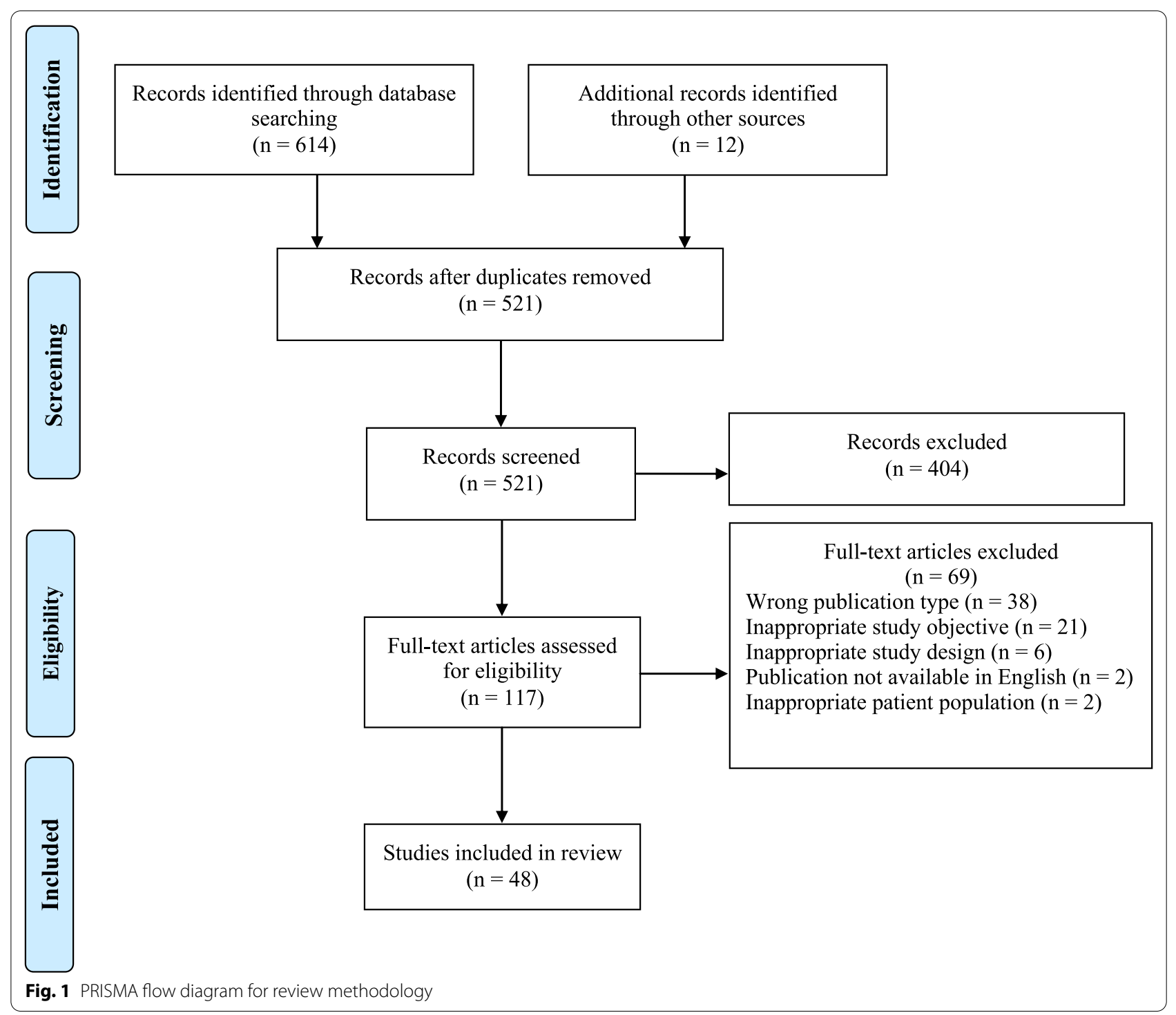

provided evidence for a strong dose-response pattern between cannabis use and the risk of $H \& N$ malignancy, while also reporting a synergistic effect of cannabis use and cigarette smoking on cancer risk [61]. This area was an unresolved knowledge gap in this scoping review.

Level of evidence: Mostly 4.

\section{Otology}

The second most studied subspeciality area was otology, where eight studies evaluated cannabis' association with hearing loss $(n=6)$, vestibular dysfunction $(\mathrm{n}=3)$ and tinnitus $(\mathrm{n}=2)[22,31,38,44,51,52,57$, 58]. Please note that one study may have addressed several otologic side effects. Exposure to cannabis was also shown to promote changes in the auditory pathway and alter the function of outer hair cells, while chronic use of cannabis at high doses showed significant changes in vestibular function $[22,52,57,58]$. There were several excellent basic science otology studies, however, they were excluded because the goal was to keep a clinical focus for this review. Four of the eight otology studies were randomized controlled trials, so the level of evidence was highest for this subspecialty area.

Level of Evidence: 2 and 4.

\section{Rhinology}

In rhinology, all five studies reported positive association between sinusitis $(n=4)$ and allergic rhinitis 
$(\mathrm{n}=2)[31,33,53,56,63]$. One rhinology study evaluated both diagnoses [56]. Cannabis smoking was associated with sinusitis in a large retrospective analysis of the US National Survey on Drug Use and Health database $(n=29,195)$, which was the largest sample size of all the studies in this scoping review [31]. Stokes et al. provided evidence to support cannabis as a clinically relevant aeroallergen on multi-test skin testing [53]. There was the least controversy in this subspecialty area.

Level of Evidence: 3 and 4.

\section{Airway}

Five studies reported cannabis and its associations with upper airway issues, including sleep apnea $(n=3)$ and dyspnea $(n=2)[23,31,48,54,63]$. Four studies described no change in risk following cannabis exposure and one study reported an increased risk. Primary evidence supports cannabinoids as a promising and safe treatment option for OSA [48]. One of the randomized controlled trials also concluded that there was no significant difference in adverse events between patients who were treated with cannabis and placebo [23]. A recent position statement by the American Academy of Sleep Medicine, however, recommended against medical cannabis for the treatment of OSA due to unreliable delivery methods and insufficient evidence of effectiveness, tolerability, and safety [64].

Level of Evidence: 2, 3, and mostly 4.

\section{Laryngology}

Only one study in laryngology explored the effect of cannabis on the voice [43]. This older study published in 1980 reported that marijuana users did not differ perceptually from non-smokers and cigarette smokers, and objective voice analysis was also similar. Darker vocal folds were seen on laryngoscopy. This subspecialty was the weakest with the largest knowledge gap.

Level of evidence: 4.

\section{Risk of bias assessment}

Overall risk of bias for all RCTs was determined to be high, with some concerns in two studies, and low in the remaining three randomized studies ("Appendix B"). Bias in nonrandomized trials was moderate in 21 studies, serious in 12, and critical in 10 studies ("Appendix C"). The major sources of bias among serious and critical studies were due to selection bias, deviations from intended interventions, confounding and inappropriate methods to control for measured confounders. The majority of nonrandomized studies demonstrated appropriate measurement of outcomes and reporting of outcome data.

\section{Discussion}

It is evident from this review that the Otolaryngology cannabis literature is limited but evolving. The included reports demonstrate that unintended side effects in otolaryngology cover a large spectrum of physiology and pathology. These included: tinnitus, vertigo, hearing loss, infection, malignancy, sinusitis, allergic rhinitis, thyroid dysfunction, and dyspnea.

A number of challenges were observed in the included studies. Many studies contained small sample sizes with methodological errors, substantial heterogeneity of study types and varied outcome measures. A lack of standardization in the reporting of quantity, method of consumption, and length of time of cannabis use was common. Similar to cigarette smoking, several studies attempted to use pack-years, but this was inconsistent. Standard medical practice depends on patient self-reporting cannabis use, which leads to recall bias in the literature. Other studies inconsistently used measures to quantify the amount of cannabis in their experimental protocol (e.g. weight, puffs, joints). This did not always control for the type of cannabis, which has the potential to alter expected results substantially. The included studies were published over several decades, however an improvement in the quality of papers were seen over time. Five recent studies were RCTs, suggesting that as cannabis gains widespread acceptance, the medical community recognizes the need for robust evidence. Lastly, challenges arise when studying cannabis consumption with concomitant tobacco and alcohol use. The carcinogenic effects of cannabis, when smoked, is certainly another area of relevance. Although these factors were controlled for by some studies, they will remain confounders until their relationship can be explored entirely.

The medical use of cannabis is legal in 33 US states, and since 2012, 11 states have legalized recreational use of the drug [65]. Conservative estimates project legal cannabis sales to reach $\$ 30$ billion by 2025 , driven mainly by increased legalization of the drug across the country [66]. This swift legalization of cannabis and growth of related industry is likely to lead to the assumption among the general public that cannabis has an adequate safety profile, analogous to the perceived safety, and subsequent increase in consumption of alcohol following prohibition in the 1930's $[67,68]$. Anecdotally, cannabis has been used to treat a large variety of conditions ranging from acute pain and psychiatric diagnoses, to chronic inflammatory conditions [69]. However, only three indications have substantial evidence demonstrating cannabis as an effective treatment alternative. These include chronic pain in adults, oral antiemetic therapy in chemotherapy-induced nausea and vomiting, and an improvement in patient reported spasticity in multiple 
Table 1 Studies reporting risk of otolaryngology-related side effects following cannabis exposure

\begin{tabular}{|c|c|c|c|c|c|c|c|c|}
\hline Study & Study type & $\begin{array}{l}\text { Level of } \\
\text { evidence }\end{array}$ & Subspeciality & No. of participants & Sex & Tobacco use & Cannabis use & Main findings \\
\hline Ahrens and Bressi [16] & Case series & 4 & Head and neck & 5 & $60 \% M$ & $80 \%$ & $100 \%$ & $\begin{array}{l}5 / 5 \text { marijuana users } \\
\text { developed an erythro- } \\
\text { plastic lesion, and } 2 / 5 \\
\text { users were determined } \\
\text { to have a malignant } \\
\text { lesion }\end{array}$ \\
\hline Ahrens and Bressi [17] & Case series & 4 & Head and neck & 178 & $57 \% \mathrm{M}$ & $100 \%$ & $22 \%$ & $\begin{array}{l}10 / 39 \text { tobacco and } \\
\text { marijuana users devel- } \\
\text { oped oral cancer }\end{array}$ \\
\hline Aldington et al. [18] & Case-control & 4 & Head and neck & 394 & $51 \% \mathrm{M}$ & $53 \%$ & $14 \%$ & $\begin{array}{l}\text { The highest tertile of } \\
\text { cannabis use (>8.3 } \\
\text { JY) was associated } \\
\text { with a nonsignificant } \\
\text { increased risk of cancer } \\
(\mathrm{RR}=1.6 ; 95 \% \mathrm{Cl} 0.5-52)\end{array}$ \\
\hline Berthiller et al. [19] & Case-control & 4 & Head and neck & 9044 & $74 \% \mathrm{M}$ & $74 \%$ & $13 \%$ & $\begin{array}{l}\text { No association with } \\
\text { marijuana use and risk } \\
\text { of H\&N cancer observed } \\
(\mathrm{OR}=0.88 ; 95 \% \mathrm{Cl} \\
0.67-1.16)\end{array}$ \\
\hline $\begin{array}{l}\text { Bhattacharyya et al. } \\
\text { [20] }\end{array}$ & Cross-sectional & 4 & Head and neck & 83 & $100 \% \mathrm{M}$ & $57 \%$ & $30 \%$ & $\begin{array}{l}\text { Overexpression of } \\
\text { EGFR onco-proteins is } \\
\text { correlated to cannabis } \\
\text { smoking }(p<0.01)\end{array}$ \\
\hline Bonnet [21] & Cross-sectional & 4 & Head and neck & 39 & $80 \% \mathrm{M}$ & N/A & $100 \%$ & $\begin{array}{l}\text { All tested patients were } \\
\text { found to have } T S H \text {, total } \\
T_{3} \text {, and free } T_{4} \text { levels } \\
\text { within the normal range }\end{array}$ \\
\hline Brumbach et al. [22] & Cross-sectional & 4 & Otology & 40 & $48 \% \mathrm{M}$ & $0 \%$ & $50 \%$ & $\begin{array}{l}\text { No significant differ- } \\
\text { ence was observed in } \\
\text { behavioural hearing } \\
\text { thresholds between } \\
\text { smokers and nonsmok- } \\
\text { ers }(p>0.05)\end{array}$ \\
\hline Carley et al. [23] & $\mathrm{RCT}$ & 2 & Airway & 73 & $71 \% \mathrm{M}$ & $\mathrm{N} / \mathrm{A}$ & $66 \%$ & $\begin{array}{l}\text { The proportion of } \\
\text { adverse events did not } \\
\text { differ between the OSA } \\
\text { patients in the placebo } \\
\text { and treatment groups } \\
(p=0.16)\end{array}$ \\
\hline Cook et al. [24] & Cross-sectional & 4 & Head and neck & 1,010 & $100 \% \mathrm{~F}$ & $5 \%$ & $4 \%$ & $\begin{array}{l}\text { Oral HPV infection were } \\
\text { associated with smok- } \\
\text { ing marijuana }(p=0.03)\end{array}$ \\
\hline $\begin{array}{l}\text { Darling and Arendorf } \\
\text { [25] }\end{array}$ & Cohort & 3 & Head and neck & 579 & N/A & $71 \%$ & $46 \%$ & $\begin{array}{l}\text { Cannabis users did not } \\
\text { show greater preva- } \\
\text { lence of leukoplakia } \\
\text { when compared with } \\
\text { control groups }\end{array}$ \\
\hline Darling et al. [26] & Cohort & 3 & Head and neck & 48 & $100 \% \mathrm{M}$ & $67 \%$ & $33 \%$ & $\begin{array}{l}\text { No significant difference } \\
\text { in the effect of cannabis } \\
\text { on the epithelial cells of } \\
\text { the oral cavity }\end{array}$ \\
\hline Darling et al. [27] & Cross-sectional & 4 & Head and neck & 163 & N/A & $69 \%$ & $34 \%$ & $\begin{array}{l}\text { Cannabis smoking } \\
\text { significantly increases } \\
\text { the prevalence of oral } \\
\text { C. albicans compared } \\
\text { to tobacco only smok- } \\
\text { ers and non-smokers } \\
(p=0.022)\end{array}$ \\
\hline Donald [28] & Case series & 4 & Head and neck & 6 & $100 \% \mathrm{M}$ & $66 \%$ & $100 \%$ & $\begin{array}{l}\text { Chronic marijuana use } \\
\text { may be a contributor to } \\
\text { H\&N cancer production } \\
\text { in young patients }\end{array}$ \\
\hline
\end{tabular}


Table 1 (continued)

\begin{tabular}{|c|c|c|c|c|c|c|c|c|}
\hline Study & Study type & $\begin{array}{l}\text { Level of } \\
\text { evidence }\end{array}$ & Subspeciality & No. of participants & Sex & Tobacco use & Cannabis use & Main findings \\
\hline Feng et al. [29] & Case-control & 4 & Head and neck & 1,251 & $69 \% \mathrm{M}$ & $41 \%$ & $6 \%$ & $\begin{array}{l}\text { Ever consumption of } \\
\text { cannabis was signifi- } \\
\text { cantly associated with } \\
\text { increased nasopharyn- } \\
\text { geal carcinoma risk } \\
(p<0.025)\end{array}$ \\
\hline Gillison et al. [30] & Case-control & 4 & Head and neck & 562 & $79 \% \mathrm{M}$ & $86 \%$ & $18 \%$ & $\begin{array}{l}\text { Marijuana smoking was } \\
\text { strongly associated with } \\
\text { HPV-16-positive HNSCC } \\
\text { in a dose-response } \\
\text { relationship (OR=4.7; } \\
95 \% \mathrm{Cl} 1.3-17 \text { ) }\end{array}$ \\
\hline Han et al. [31] & Cross-sectional & 4 & $\begin{array}{l}\text { OtologyRhinolo- } \\
\text { gyAirway }\end{array}$ & 29,195 & N/A & $19 \%$ & $39 \%$ & $\begin{array}{l}\text { Marijuana use increases } \\
\text { the occurrence of } \\
\text { sinusitis (OR=1.23; } \\
95 \% \mathrm{Cl} 0.99-1.28) \text {, but } \\
\text { has no effect on sleep } \\
\text { apnea }(\mathrm{OR}=1.20 ; 95 \% \mathrm{Cl} \\
0.92-1.56) \text { and tin- } \\
\text { nitus }(\mathrm{OR}=1.14 ; 95 \% \mathrm{Cl} \\
0.77-1.70)\end{array}$ \\
\hline Hashibe et al. [32] & Case-control & 4 & Head and neck & 2,252 & $61 \% \mathrm{M}$ & $65 \%$ & $54 \%$ & $\begin{array}{l}\text { No association } \\
\text { observed between } \\
\text { marijuana use and } \\
\text { oral }(\mathrm{OR}=1.1 ; 95 \% \mathrm{Cl} \\
0.8-1.5) \text {, pharyngeal } \\
(\mathrm{OR}=0.75 ; 95 \% \mathrm{Cl} \\
0.37-1.5) \text {, or laryngeal } \\
(\mathrm{OR}=0.93 ; 95 \% \mathrm{Cl} \\
0.5-1.7) \text { cancer }\end{array}$ \\
\hline Henderson et al. [33] & Case series & 4 & Rhinology & 200 & $100 \% \mathrm{M}$ & $90 \%$ & $100 \%$ & $\begin{array}{l}26 / 200 \text { patients } \\
\text { presented with rhinitis } \\
\text { and } 150 / 200 \text { patient } \\
\text { had symptoms of } \\
\text { pharyngitis }\end{array}$ \\
\hline Herning et al. [34] & Cross-sectional & 4 & Head and neck & 108 & $60 \% \mathrm{M}$ & N/A & $69 \%$ & $\begin{array}{l}\text { Marijuana users that } \\
\text { used for }>8 \text { years had } \\
\text { lower } \mathrm{T}_{4}(p<0.01) \\
\text { and higher } \mathrm{T}_{3} \text { uptake } \\
(p<0.05) \text { levels com- } \\
\text { pared to short term } \\
\text { marijuana users }\end{array}$ \\
\hline Hess et al. [35] & Case-control & 4 & Head and neck & 162 & $88 \% \mathrm{M}$ & $\mathrm{N} / \mathrm{A}$ & $43 \%$ & $\begin{array}{l}\text { HPV-negative patients } \\
\text { has higher rates of mari- } \\
\text { juana use compared to } \\
\text { HPV-positive patients } \\
(p=0.003)\end{array}$ \\
\hline Kagen et al. [36] & Cross-sectional & 4 & Head and neck & 38 & $43 \% \mathrm{M}$ & $64 \%$ & $74 \%$ & $\begin{array}{l}\text { Marijuana smoking } \\
\text { sensitizes patients to } \\
\text { Aspergillus }\end{array}$ \\
\hline Liang et al. [37] & Case-control & 4 & Head and neck & 981 & $73 \% \mathrm{M}$ & $73 \%$ & $27 \%$ & $\begin{array}{l}\text { Moderate marijuana } \\
\text { use ( } 10-20 \text { years) } \\
\text { was associated with a } \\
\text { reduced risk of HNSCC } \\
(\mathrm{OR}=0.52 ; 95 \% \mathrm{Cl} \\
0.34-0.89)\end{array}$ \\
\hline Liedgren et al. [38] & $\mathrm{RCT}$ & 2 & Otology & 30 & $77 \% \mathrm{M}$ & $\mathrm{N} / \mathrm{A}$ & $100 \%$ & $\begin{array}{l}\text { Marijuana has no effect } \\
\text { on hearing acuity as } \\
\text { assessed by pure tone } \\
\text { threshold, speech } \\
\text { reception threshold, } \\
\text { speech discrimination, } \\
\text { and acoustic imped- } \\
\text { ance measurement }\end{array}$ \\
\hline
\end{tabular}


Table 1 (continued)

\begin{tabular}{|c|c|c|c|c|c|c|c|c|}
\hline Study & Study type & $\begin{array}{l}\text { Level of } \\
\text { evidence }\end{array}$ & Subspeciality & No. of participants & Sex & Tobacco use & Cannabis use & Main findings \\
\hline Llewellyn et al. [39] & Case-control & 4 & Head and neck & 323 & $56 \% M$ & $69 \%$ & $11 \%$ & $\begin{array}{l}\text { No significant } \\
\text { association between } \\
\text { cannabis use and oral } \\
\text { cancer }(\mathrm{OR}=1.0 ; 95 \% \mathrm{Cl} \\
0.5-2.2 \text {.) }\end{array}$ \\
\hline Llewellyn et al. [40] & Case-control & 4 & Head and neck & 144 & $53 \% \mathrm{M}$ & $69 \%$ & $13 \%$ & $\begin{array}{l}\text { No significant } \\
\text { association between } \\
\text { cannabis use and oral } \\
\text { cancer }(\mathrm{OR}=0.3 ; 95 \% \mathrm{Cl} \\
0.1-1.8 \text {.) }\end{array}$ \\
\hline Malhotra et al. [41] & Cross-sectional & 4 & Head and neck & 5,280 & $50 \%$ & $\mathrm{~N} / \mathrm{A}$ & $55 \%$ & $\begin{array}{l}\text { Recent marijuana use } \\
\text { was not associated with } \\
\text { thyroid dysfunction, but } \\
\text { was significantly associ- } \\
\text { ated with lower levels } \\
\text { of TSH (0.344; } 95 \% \text { Cl } \\
0.127-0.928)\end{array}$ \\
\hline Marks et al. [42] & Case-control & 4 & Head and neck & 9,916 & $71 \% \mathrm{M}$ & $66 \%$ & $16 \%$ & $\begin{array}{l}\text { Marijuana use was asso- } \\
\text { ciated with an elevated } \\
\text { risk of oropharyngeal } \\
\text { cancer }(\mathrm{OR}=1.24 \text {; } \\
95 \% \mathrm{Cl} 1.06-1.47) \text {, } \\
\text { and a reduced risk of } \\
\text { oral tongue cancer } \\
(\mathrm{OR}=0.47 ; 95 \% \mathrm{Cl} \\
0.29-0.75) \text {. Possible } \\
\text { association with HPV }\end{array}$ \\
\hline $\begin{array}{l}\text { Mueller and Wilcox } \\
\text { [43] }\end{array}$ & Cross-sectional & 4 & Laryngology & 35 & $26 \% M$ & $29 \%$ & $40 \%$ & $\begin{array}{l}\text { Marijuana users did } \\
\text { not differ perceptually } \\
\text { from nonsmokers and } \\
\text { tobacco smokers in } \\
\text { vocal pitch, vocal qual- } \\
\text { ity, and fundamental } \\
\text { frequency; however, } \\
\text { users had darker vocal } \\
\text { cords on indirect laryn- } \\
\text { goscopy }\end{array}$ \\
\hline Mulheran et al. [44] & $\mathrm{RCT}$ & 2 & Otology & 8 & $100 \% \mathrm{M}$ & N/A & $100 \%$ & $\begin{array}{l}\text { THC does not appear to } \\
\text { have a profound effect } \\
\text { on the processing of } \\
\text { elementary stimuli by } \\
\text { the auditory pathway as } \\
\text { assessed by pure tone } \\
\text { audiometry }\end{array}$ \\
\hline Muller et al. [45] & Case-control & 4 & Head and neck & 289 & $53 \% \mathrm{M}$ & $70 \%$ & $48 \%$ & $\begin{array}{l}\text { Marijuana use was asso- } \\
\text { ciated with oral HPV } \\
\text { detection in HIV-nega- } \\
\text { tive patients (OR=4.0; } \\
95 \% \mathrm{Cl} 1.3-12.4) \text {, but not } \\
\text { HIV-positive patients }\end{array}$ \\
\hline Newman et al. [46] & Cross-sectional & 4 & Head and neck & 39 & $85 \% \mathrm{M}$ & N/A & $51 \%$ & $\begin{array}{l}\text { Marijuana use was asso- } \\
\text { ciated with a change of } \\
\text { the oral microbiota at } \\
\text { the oral pharyngeal site } \\
\text { that were more consist- } \\
\text { ent with cancer }\end{array}$ \\
\hline Parshad et al. [47] & Case-control & 4 & Head and neck & 56 & $100 \% \mathrm{M}$ & $0 \%$ & $100 \%$ & $\begin{array}{l}\text { Serum } T_{3} \text { levels were } \\
\text { lower in smokers com- } \\
\text { pared to non-smokers } \\
(p<0.05)\end{array}$ \\
\hline Prasad et al. [48] & Case series & 4 & Airway & 17 & $35 \% \mathrm{M}$ & $\mathrm{N} / \mathrm{A}$ & $100 \%$ & $\begin{array}{l}\text { Dronabinol treatment } \\
\text { is safe and significantly } \\
\text { reduces the apnea- } \\
\text { hypopnea index in } \\
\text { patients with sleep } \\
\text { apnea ( } p=0.003 \text { ) }\end{array}$ \\
\hline
\end{tabular}


Table 1 (continued)

\begin{tabular}{|c|c|c|c|c|c|c|c|c|}
\hline Study & Study type & $\begin{array}{l}\text { Level of } \\
\text { evidence }\end{array}$ & Subspeciality & No. of participants & Sex & Tobacco use & Cannabis use & Main findings \\
\hline Rosenblatt et al. [49] & Case-control & 4 & Head and neck & 1,022 & $71 \% \mathrm{M}$ & $78 \%$ & $25 \%$ & $\begin{array}{l}\text { No association } \\
\text { observed between } \\
\text { marijuana use and } \\
\text { OSCC }(\mathrm{OR}=0.9 ; 95 \% \mathrm{Cl} \\
0.6-1.3)\end{array}$ \\
\hline Shah et al. [50] & Case-control & 4 & Head and neck & 1,000 & $80 \% \mathrm{M}$ & $27 \%$ & $1 \%$ & $\begin{array}{l}\text { Patients with head } \\
\text { and neck cancer were } \\
\text { more likely to smoke } \\
\text { marijuana }(\mathrm{OR}=1.6)\end{array}$ \\
\hline Spector [51] & $\mathrm{RCT}$ & 2 & Otology & 72 & $\mathrm{~N} / \mathrm{A}$ & $\mathrm{N} / \mathrm{A}$ & $100 \%$ & $\begin{array}{l}\text { No vestibular effect was } \\
\text { observed after smoking } \\
\text { marijuana }\end{array}$ \\
\hline Spector [52] & Cross-sectional & 4 & Otology & 89 & $56 \%$ & $\mathrm{~N} / \mathrm{A}$ & $73 \%$ & $\begin{array}{l}\text { No auditory differences } \\
\text { observed between } \\
\text { chronic marijuana } \\
\text { users and controls, but } \\
\text { significant changes in } \\
\text { vestibular function seen } \\
\text { in chronic marijuana } \\
\text { users as assessed by } \\
\text { electronystagmography }\end{array}$ \\
\hline Stokes et al. [53] & Cohort & 3 & Rhinology & 127 & $\mathrm{~N} / \mathrm{A}$ & $\mathrm{N} / \mathrm{A}$ & $\mathrm{N} / \mathrm{A}$ & $\begin{array}{l}78 / 128 \text { patients were } \\
\text { skin test positive to } \\
\text { cannabis, and } 22 / 30 \\
\text { of the patients with } \\
\text { positive skin testing has } \\
\text { respiratory symptoms } \\
\text { consistent with allergic } \\
\text { rhinitis }\end{array}$ \\
\hline Tashkin et al. [54] & Cohort & 3 & Airway & 299 & $67 \% \mathrm{M}$ & $69 \%$ & $93 \%$ & $\begin{array}{l}\text { Compared to nonsmok- } \\
\text { ers, marijuana smokers } \\
\text { did not report a } \\
\text { significantly increased } \\
\text { percentage of dyspnea }\end{array}$ \\
\hline Taylor [55] & Case series & 4 & Head and neck & 10 & $60 \% \mathrm{M}$ & $60 \%$ & $70 \%$ & $\begin{array}{l}7 / 10 \text { patients with res- } \\
\text { piratory tract carcinoma } \\
\text { were marijuana users }\end{array}$ \\
\hline Tennant et al. [56] & Cohort & 3 & Rhinology & 31 & $100 \% \mathrm{M}$ & $68 \%$ & $100 \%$ & $\begin{array}{l}\text { 12/31 hashish users pre- } \\
\text { sented with symptoms } \\
\text { of rhinopharyngitis }\end{array}$ \\
\hline Weich et al. [57] & Cross-sectional & 4 & Otology & 17 & $\mathrm{~N} / \mathrm{A}$ & $\mathrm{N} / \mathrm{A}$ & $59 \%$ & $\begin{array}{l}7 / 17 \text { users reported } \\
\text { hearing loss; } 6 / 17 \text { users } \\
\text { reported dizziness; } 6 / 17 \\
\text { users reported tinnitus }\end{array}$ \\
\hline $\begin{array}{l}\text { Winton-Brown et al. } \\
\text { [58] }\end{array}$ & $\mathrm{RCT}$ & 2 & Otology & 14 & $100 \% \mathrm{M}$ & N/A & $100 \%$ & $\begin{array}{l}\text { THC attenuated activa- } \\
\text { tion in the primary and } \\
\text { secondary auditory } \\
\text { regions of the brain } \\
\text { bilaterally relative to } \\
\text { placebo }(p=0.0006)\end{array}$ \\
\hline Xie et al. [59] & Case-control & 4 & Head and neck & 879 & $72 \% \mathrm{M}$ & $52 \%$ & $8 \%$ & $\begin{array}{l}\text { A higher rate of } \\
\text { oropharynx cancer was } \\
\text { observed within mari- } \\
\text { juana users }(p<0.0001) \text {; } \\
\text { marijuana users had a } \\
\text { higher rate of HPV-16 } \\
\text { positive oropharyngeal } \\
\text { cancer ( } p=0.002 \text { ) }\end{array}$ \\
\hline Zhang et al. [60] & Case-control & 4 & Head and neck & 349 & $63 \% M$ & $72 \%$ & $12 \%$ & $\begin{array}{l}\text { The risk of HNSCC is } \\
\text { increased with mari- } \\
\text { juana use compared } \\
\text { to no use in a dose- } \\
\text { response relationship } \\
(\mathrm{OR}=2.6 ; 95 \% \mathrm{Cl} \\
1.1-6.6)\end{array}$ \\
\hline
\end{tabular}


Table 1 (continued)

\begin{tabular}{|c|c|c|c|c|c|c|c|c|}
\hline Study & Study type & $\begin{array}{l}\text { Level of } \\
\text { evidence }\end{array}$ & Subspeciality & No. of participants & Sex & Tobacco use & Cannabis use & Main findings \\
\hline Zhang et al. [61] & Case-control & 4 & Head and neck & 284 & $64 \% \mathrm{M}$ & $76 \%$ & $11 \%$ & $\begin{array}{l}\text { Marijuana use com- } \\
\text { bined with environ- } \\
\text { mental tobacco smoke } \\
\text { exposure is a potential } \\
\text { risk factor for HNSCC } \\
(\mathrm{OR}=7.1 ; 95 \% \mathrm{Cl} \\
1.5-34.5)\end{array}$ \\
\hline Zhang et al. [62] & Cohort & 3 & Head and neck & 94 & $81 \% \mathrm{M}$ & $24 \%$ & $50 \%$ & $\begin{array}{l}\text { No survival difference } \\
\text { between HPV-related } \\
\text { OPSCC marijuana users } \\
\text { and non-users in 2-year } \\
\text { and 5-year survival } \\
(p=0.400)\end{array}$ \\
\hline Zuskin et al. [63] & Cross-sectional & 4 & AirwayRhinology & 190 & $24 \% \mathrm{M}$ & $34 \%$ & $100 \%$ & $\begin{array}{l}\text { Male and female hemp } \\
\text { works experienced a } \\
\text { significantly higher } \\
\text { prevalence of sinusitis } \\
\text { compared to controls; } \\
\text { female works also } \\
\text { experienced a higher } \\
\text { prevalence of dyspnea }\end{array}$ \\
\hline
\end{tabular}

JY, Joint years; EGFR, epidermal growth factor receptor; OSA, obstructive sleep apnea; HPV, human papillomavirus; HNSCC, head and neck squamous cell carcinoma; OSCC, oral squamous cell carcinoma; OPSCC, oropharyngeal squamous cell carcinoma; OR, odds ratio; N/A, not applicable

sclerosis [70]. Outside of these few indications, there is limited and conflicting evidence to support the effectiveness of cannabis as a primary treatment for most medical conditions. This trend is similarly demonstrated in our review, with a disparity in consistency of the reported side effects. As we learn more about cannabis, we will likely understand that there are many more interactions and side effects associated with varying amounts of use. Many of these effects will likely not be observed for years, when evidence on chronic use begin to emerge. Conversely, there is the possibility for positive uses that remain to be realized. Given this, it would be appropriate for all health practitioners to develop and incorporate a better understanding of this drug into their practice as the literature continues to evolve.

There are obvious gaps in the knowledge of how cannabis affects otolaryngology, but this also suggests extensive opportunities for further research. Every subspecialty of Otolaryngology remains a potential area for further study. Presently, the areas of H\&N oncology, otology and allergy demonstrate convincing effects of cannabis, making them easy study prospects. Furthermore, the quantification of cannabis use over time and understanding the potential risks may lead to harm reduction campaigns, notably with young and heavy users.

A small number of recent systematic reviews have studied cannabis in subspecialties within Otolaryngology, such as laryngology and H\&N oncology. MeehanAtrash et al. in [4], assessed the association between inhaled cannabis and voice disorders. Similar to our review, the group only identified a single clinical study specific to voice. De Carvalho et al. in [10] performed a meta-analysis to establish the relationship between marijuana and $H \& N$ cancer. This group reported no association between lifetime marijuana use and $H \& N$ malignancy. Although these researchers were able to reach a conclusion on $\mathrm{H} \& \mathrm{~N}$ cancer risk, the findings of our review have dissuaded us from doing the same as we believe that much of the H\&N oncology literature is divided and still in its infancy. Furthermore, de Carvalho et al. (2015) limited their meta-analysis to case-control studies. Considering the cannabis literature has evolved significantly since 2015, we believe that higher-quality studies, including longitudinal studies, are needed to reach a clear consensus. A narrative review on the evidence for the use of cannabis in otolaryngology was recently completed by Valentino and Mckinnon. However, they did not adhere to PRISMA guidelines and perform a scoping review of the literature [9]. They did not use the Oxford Centre for Evidence-Based Medicine Levels of Evidence or perform a risk of bias assessment to evaluate the quality of the studies.

The strengths of this scoping review included the rigorous PRISMA methodology, comprehensive peer reviewed search strategy, and the inclusion of a fair number of reports. This was an ideal methodology to study this topic, as scoping reviews are useful for evaluating emerging evidence. Broad areas can be examined to identify knowledge gaps and show how research is currently being conducted in this field, helping to define more 


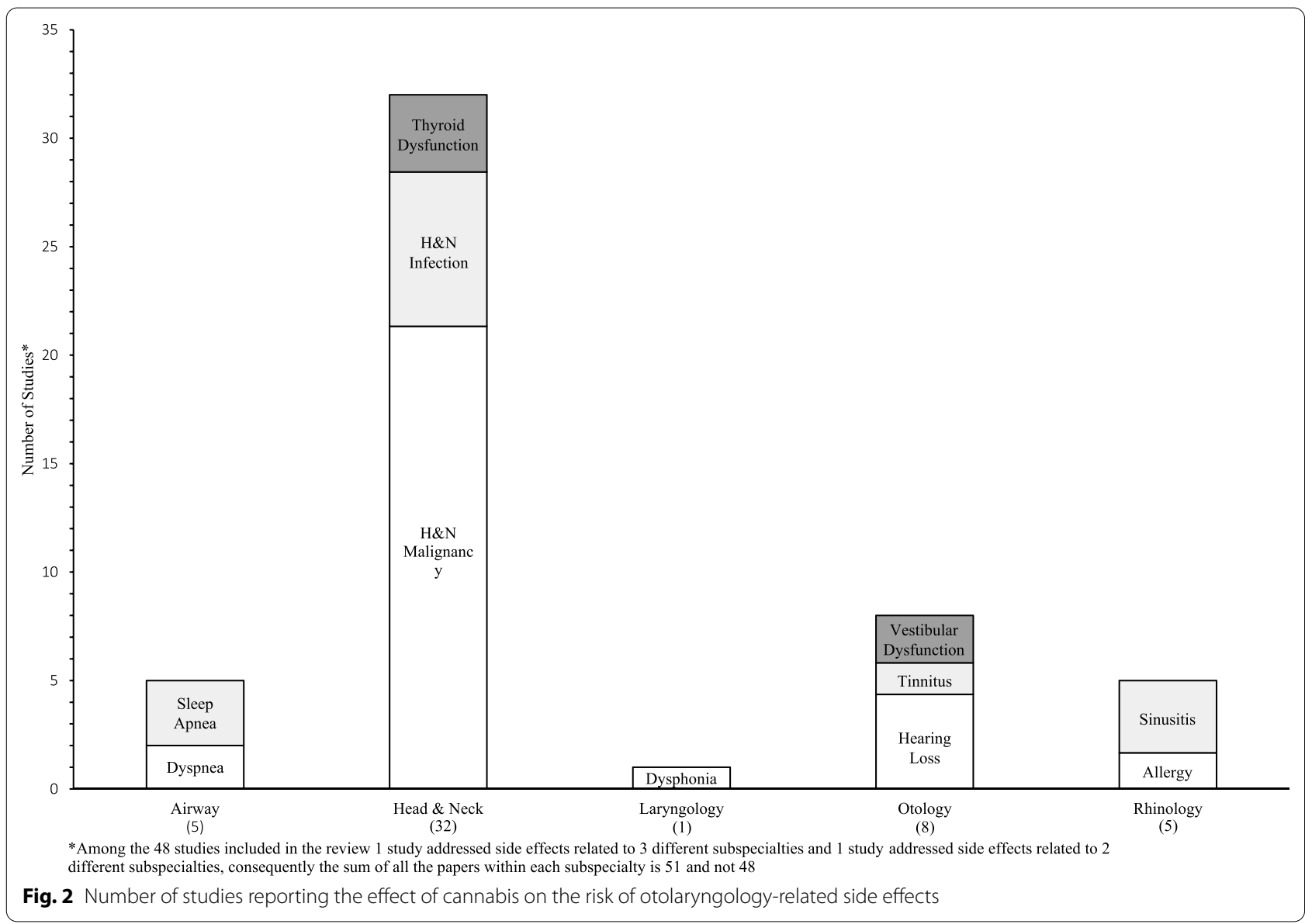

precise questions. Recognizing the heterogeneity of the literature, the choice to use a scoping review methodology allowed for data synthesis, hypothesis generation and will serve as a precursor for systematic reviews and future study in this early field. Lastly, this review was the first to group unintended side effects to each subspecialty, and attempt to define a preliminary risk profile of cannabis (i.e. Head and neck malignancy).

There were some limitations. This review was limited to English language studies only. Case studies with less than five patients were excluded to ensure that only higher-quality studies were included. This decision may have excluded very rare side effects. Furthermore, given the multiple methods of cannabis consumption, the severity and degree of side effects may vary. This will likely be overcome as the Cannabis literature becomes more robust. Basic science studies were excluded to maintain a clinical focus in this review. The study was limited to the adult population because most jurisdictions require a legal age limit to consume cannabis.

\section{Conclusion}

This scoping review was undertaken to better understand the safety profile of cannabis and its potential for unintended side effects related to Otolaryngology. Although the quality of evidence in the included reports was lacking, it has provided an overview of the available literature, potential pitfalls or challenges to study design, and was hypothesis-generating. This review indicated that cannabis use is associated with several side effects, including hearing loss, H\&N malignancy, and HPV infection. However, much of the H\&N literature remains divided on the actual risk of cannabis use. Significant opportunities exist for the otolaryngology community to better investigate the therapeutic effects of cannabis with highquality studies, particularly on the risk of long-term use and harm reduction. As the rapidly evolving cannabis market continues to grow, clinicians will be expected to guide and counsel patients considering medical or recreational use, and it is essential that they have access to high-quality objective evidence. 


\section{Appendix A: Search strategies for MEDLINE, EMBASE, CINAHL, and CENTRAL}

\section{MEDLINE search strategy}

1. Otolaryngology/

2. Sinusitis/

3. Rhinitis/

4. Otorhinolaryngologic Diseases/

5. Ear/

6. Nose/

7. Larynx/

8. Palate/

9. Pharynx/

10. Mouth/

11. Tongue/

12. Palatine Tonsil/

13. Thyroid Gland/

14. Neck/

15. Head/

16. Neurotology/

17. Epistaxis/

18. Otitis/

19. Hearing/

20. Tinnitus/

21. Vocal Cords/

22. Vocal Cord Paralysis/

23. "Head and Neck Neoplasms"/

24. otolaryngology.mp. $[\mathrm{mp}=$ title, abstract, original title, name of substance word, subject heading word, floating sub-heading word, keyword heading word, organism supplementary concept word, protocol supplementary concept word, rare disease supplementary concept word, unique identifier, synonyms]

25. (head and neck).mp. [mp =title, abstract, original title, name of substance word, subject heading word, floating sub-heading word, keyword heading word, organism supplementary concept word, protocol supplementary concept word, rare disease supplementary concept word, unique identifier, synonyms]

26. 1 or 2 or 3 or 4 or 5 or 6 or 7 or 8 or 9 or 10 or 11 or 12 or 13 or 14 or 15 or 16 or 17 or 18 or 19 or 20 or 21 or 22 or 23 or 24 or 25

27. exp Cannabis/ or exp Cannabinoids/ or exp Marijuana Abuse/ or exp "Marijuana Use"/ or exp Medical Marijuana/ or (((blunt or blunts or pot) adj2 smok $\left.{ }^{*}\right)$ or bhang or bhangs or cannabi* or cannibinoid* or cesamet or dexanabinol or dronabinol or ganja or ganjas or "hash oil*" or hashish* or hemp or mari?uana* or marinol or nabilone or nabixi-

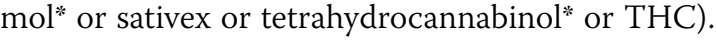
mp.

28. 26 and 27

\section{EMBASE search strategy}

1. Sinusitis/

2. Otolaryngology/

3. Rhinitis/

4. Otorhinolaryngologic Diseases/

5. Ear/

6. Larynx/

7. Palate/

8. Nose/

9. Pharynx/

10. Mouth/

11. Tongue/

12. Palatine Tonsil/

13. Thyroid Gland/

14. Neck/

15. Head/

16. Neurotology/

17. Epistaxis/

18. Otitis/

19. Hearing/

20. Tinnitus/

21. Vocal Cords/

22. Vocal Cord Paralysis/

23. "Head and Neck Neoplasms"/

24. otolaryngology.mp.

25. (head and neck).mp.

26. 1 or 2 or 3 or 4 or 5 or 6 or 7 or 8 or 9 or 10 or 11 or 12 or 13 or 14 or 15 or 16 or 17 or 18 or 19 or 20 or 21 or 22 or 23 or 24 or 25

27. cannabis smoking/ or medical cannabis/ or cannabis/ or "cannabis use"/ or Cannabis sativa/ or cannabis derivative/

28. cannabis/

29. cannabinoid/

30. cannabinoid/

31. hash.mp.

32. dronabinol/

33. tetrahydrocannabinol/

34. 27 or 28 or 29 or 30 or 31 or 32 or 33

35. 26 and 34

\section{CINAHL search strategy}

1. (MH "Otorhinolaryngologic Diseases + ")

2. (MH "Otorhinolaryngologic Neoplasms + ")

3. $\mathrm{MH}$ "Otorhinolaryngology and Head-Neck Nursing") 
4. "otolaryngology"

5. (MH "Sinusitis + ")

6. (MH "Rhinitis + ")

7. (MH "Rhinosinusitis")

8. (MH "Larynx +")

9. (MH "Head and Neck Neoplasms + ")

10. (MH "Squamous Cell Carcinoma of Head and Neck")

11. (MH "Tinnitus")

12. (MH "Vocal Cord Paralysis + ")

13. (MH "Vocal Cord Dysfunction")

14. (MH "Otitis +")

15. (MH "Thyroid Diseases + ")

16. (MH "Hearing Disorders +")

17. 1 or 2 or 3 or 4 or 5 or 6 or 7 or 8 or 9 or 10 or 11 or 12 or 13 or 14 or 15 or 16

18. (MH "Cannabis")
19. (MH "Medical Marijuana")

20. 18 or 19

21. 17 and 20

\section{CENTRAL search strategy}

1. MeSH descriptor: [Otolaryngology] explode all trees

2. MeSH descriptor: [Head and Neck Neoplasms] explode all trees

3. $\mathrm{MeSH}$ descriptor: [Otorhinolaryngologic Diseases] explode all trees

4. MeSH descriptor: [Rhinitis] explode all trees

5. MeSH descriptor: [Sinusitis] explode all trees

6. 1 or 2 or 3 or 4 or 5

7. MeSH descriptor: [Cannabis] explode all trees

8. 6 and 7

\section{Appendix B: Risk of bias assessment (Rob 2): randomized controlled trials}

\begin{tabular}{|c|c|c|c|c|c|c|}
\hline Study & $\begin{array}{l}\text { Risk of bias } \\
\text { arising from the } \\
\text { randomization process }\end{array}$ & $\begin{array}{l}\text { Risk of bias due } \\
\text { to deviations } \\
\text { from the intended } \\
\text { intervention }\end{array}$ & $\begin{array}{l}\text { Risk of bias } \\
\text { due to missing } \\
\text { outcome data }\end{array}$ & $\begin{array}{l}\text { Risk of bias in } \\
\text { measurement } \\
\text { of the outcome }\end{array}$ & $\begin{array}{l}\text { Risk of bias in } \\
\text { selection of } \\
\text { the reported } \\
\text { result }\end{array}$ & $\begin{array}{l}\text { Overall risk } \\
\text { of bias }\end{array}$ \\
\hline Carley et al. [23] & Low & Low & Low & Low & Low & Low \\
\hline Liedgren et al. [38] & Some concerns & High & Some concerns & High & Low & High \\
\hline Mulheran et al. [44] & Low & Low & Low & Low & Low & Low \\
\hline Spector [51] & Some concerns & Some concerns & Low & Low & Low & $\begin{array}{l}\text { Some con- } \\
\text { cerns }\end{array}$ \\
\hline Winton-Brown et al. [58] & Some concerns & Low & Low & Low & Low & Low \\
\hline
\end{tabular}

Appendix C: Risk of bias assessment (ROBINS-I): non-randomized studies

\begin{tabular}{|c|c|c|c|c|c|c|c|c|c|}
\hline Study & $\mathrm{Yr}$ & $\begin{array}{l}\text { Bias due to } \\
\text { confounding }\end{array}$ & $\begin{array}{l}\text { Bias in } \\
\text { selection of } \\
\text { participants } \\
\text { into the } \\
\text { study }\end{array}$ & $\begin{array}{l}\text { Bias in } \\
\text { classification } \\
\text { of } \\
\text { interventions }\end{array}$ & $\begin{array}{l}\text { Bias in } \\
\text { deviations } \\
\text { from intended } \\
\text { Interventions }\end{array}$ & $\begin{array}{l}\text { Bias } \\
\text { due to } \\
\text { missing } \\
\text { data }\end{array}$ & $\begin{array}{l}\text { Bias in } \\
\text { measurement } \\
\text { of outcomes }\end{array}$ & $\begin{array}{l}\text { Bias in } \\
\text { selection } \\
\text { of the } \\
\text { reported } \\
\text { result }\end{array}$ & Overall bias \\
\hline Ahrens [16] & 2005 & Critical & Critical & $\mathrm{NI}$ & $\mathrm{NI}$ & Low & Serious & Low & Critical \\
\hline Ahrens [17] & 2007 & Critical & Serious & Serious & Low & Low & Moderate & Low & Critical \\
\hline Aldington [18] & 2008 & Low & Moderate & Low & Low & Low & Moderate & Moderate & Moderate \\
\hline Berthiller [19] & 2009 & Low & Moderate & Low & Low & Low & Moderate & Moderate & Moderate \\
\hline $\begin{array}{l}\text { Bhattacharyya } \\
{[20]}\end{array}$ & 2015 & Serious & Moderate & Low & Low & Low & Moderate & Moderate & Serious \\
\hline Bonnet [21] & 2013 & Serious & Moderate & Low & $\mathrm{NI}$ & Moderate & Moderate & Low & Serious \\
\hline Brumbach [22] & 2019 & Low & Moderate & Low & Low & Low & Low & Low & Moderate \\
\hline Cook [24] & 2014 & Low & Moderate & Low & Low & Moderate & Moderate & Moderate & Moderate \\
\hline Darling [25] & 1993 & Serious & Serious & Low & Low & Moderate & Moderate & Low & Serious \\
\hline Darling [26] & 2002 & Serious & Serious & Low & Serious & Low & Moderate & Low & Serious \\
\hline Darling [43] & 1990 & Critical & Serious & Serious & $\mathrm{NI}$ & Low & Moderate & Low & Critical \\
\hline Donald [28] & 1986 & Critical & Serious & $\mathrm{NI}$ & $\mathrm{NI}$ & Low & $\mathrm{NI}$ & $\mathrm{NI}$ & Critical \\
\hline Feng [29] & 2019 & Low & Moderate & Low & Low & Low & Low & Low & Moderate \\
\hline Gillison [30] & 2008 & Low & Moderate & Low & Low & Low & Low & Low & Moderate \\
\hline Han [31] & 2010 & Low & Moderate & Low & Low & Low & Moderate & Moderate & Moderate \\
\hline
\end{tabular}




\begin{tabular}{|c|c|c|c|c|c|c|c|c|c|}
\hline Study & $\mathrm{Yr}$ & $\begin{array}{l}\text { Bias due to } \\
\text { confounding }\end{array}$ & $\begin{array}{l}\text { Bias in } \\
\text { selection of } \\
\text { participants } \\
\text { into the } \\
\text { study }\end{array}$ & $\begin{array}{l}\text { Bias in } \\
\text { classification } \\
\text { of } \\
\text { interventions }\end{array}$ & $\begin{array}{l}\text { Bias in } \\
\text { deviations } \\
\text { from intended } \\
\text { Interventions }\end{array}$ & $\begin{array}{l}\text { Bias } \\
\text { due to } \\
\text { missing } \\
\text { data }\end{array}$ & $\begin{array}{l}\text { Bias in } \\
\text { measurement } \\
\text { of outcomes }\end{array}$ & $\begin{array}{l}\text { Bias in } \\
\text { selection } \\
\text { of the } \\
\text { reported } \\
\text { result }\end{array}$ & Overall bias \\
\hline Hashibe [32] & 2006 & Low & Low & Low & Low & Low & Low & Low & Moderate \\
\hline Henderson [33] & 1972 & Critical & Critical & Serious & $\mathrm{NI}$ & $\mathrm{NI}$ & Serious & $\mathrm{NI}$ & Critical \\
\hline Herning [34] & 2008 & Low & Moderate & Low & Low & Low & Low & Low & Moderate \\
\hline Hess [35] & 2014 & Low & Moderate & Serious & Low & Low & Low & Low & Serious \\
\hline Kagen [36] & 1983 & Critical & Serious & Low & Low & $\mathrm{NI}$ & Moderate & Low & Critical \\
\hline Liang [37] & 2009 & Low & Moderate & Low & Low & Moderate & Low & Low & Moderate \\
\hline Llewellyn [39] & 2004 & Low & Moderate & Low & Low & Low & Low & Low & Moderate \\
\hline Llewellyn [40] & 2004 & Low & Moderate & Low & Low & Moderate & Moderate & Low & Moderate \\
\hline Malhotra [41] & 2017 & Low & Moderate & Low & Low & Low & Moderate & Low & Moderate \\
\hline Marks [42] & 2013 & Low & Moderate & Low & Low & Moderate & Low & Low & Moderate \\
\hline Mueller [43] & 1980 & Serious & Serious & Low & Serious & Serious & Low & Low & Serious \\
\hline Muller [45] & 2015 & Low & Moderate & Low & Low & Moderate & Low & Low & Moderate \\
\hline Newman [46] & 2019 & Critical & Serious & Low & Serious & Low & Moderate & Low & Critical \\
\hline Parshad [47] & 1983 & Serious & Serious & Low & $\mathrm{Nl}$ & Low & Low & Low & Serious \\
\hline Prasad [48] & 2013 & Serious & Low & Low & $\mathrm{NI}$ & Serious & Low & Low & Serious \\
\hline Rosenblatt [49] & 2004 & Low & Moderate & Low & Low & Low & Low & Low & Moderate \\
\hline Shah [50] & 2018 & Serious & Serious & Serious & Serious & Low & Low & Low & Serious \\
\hline Spector [52] & 1974 & Critical & Serious & Low & Serious & Low & Low & Low & Critical \\
\hline Stokes [53] & 2000 & Serious & Serious & Serious & Serious & Low & Serious & Low & Serious \\
\hline Tashkin [54] & 2012 & Low & Moderate & Low & Low & Moderate & Moderate & Low & Moderate \\
\hline Taylor [55] & 1988 & Critical & Critical & Critical & Serious & Moderate & Serious & Low & Critical \\
\hline Tennant [56] & 1971 & Critical & Serious & Critical & Serious & Serious & Serious & Moderate & Critical \\
\hline Weich [57] & 2012 & Serious & Serious & Moderate & Serious & Low & Serious & Low & Serious \\
\hline Xie [59] & 2018 & Low & Moderate & Low & Low & Low & Low & Low & Moderate \\
\hline Zhang [60] & 1999 & Low & Moderate & Low & Low & Low & Low & Low & Moderate \\
\hline Zhang1 [11] & 2000 & Low & Moderate & Low & Low & Moderate & Low & Low & Moderate \\
\hline Zhang [62] & 2019 & Low & Moderate & Low & Low & Low & Low & Low & Moderate \\
\hline Zuskin [63] & 1990 & Serious & Serious & Serious & Serious & Low & Moderate & Low & Serious \\
\hline
\end{tabular}

$\mathrm{NI}$, no information.

Abbreviations

HPV: Human papilloma virus; OSA: Obstructive sleep apnea; H\&N: Head and neck; RTC: Randomized control trial.

\section{Acknowledgements}

Not applicable.

\section{Authors' contributions}

JP was a part of drafting the research protocol, abstract and full text screening for study selection, data collection and analysis, risk of bias assessment, preparation of manuscript and revisions of final manuscript. JH was part of the abstract and full text screening for study selection, risk of bias assessment, preparation of manuscript and revisions of final manuscript. AH conceived the project \& research protocol. She resolved differences in abstract selection, full text paper selection, and risk of bias assessment. They revised the manuscript critically for important intellectual content. All authors read and approved the final manuscript.

\section{Funding}

Not applicable.
Availability of data materials

The datasets used and/or analysed during the current study are either included in this published article or are available from the corresponding author on reasonable request.

\section{Declarations}

Ethics approval and consent to participate

Not applicable.

\section{Consent for publication}

Not applicable.

\section{Competing interests}

None of the authors have any competing interests.

Received: 2 March 2021 Accepted: 5 August 2021

Published online: 27 September 2021 


\section{References}

1. Bose J, Hedden SL, Lipari RN, Park-Lee E. Key Substance Use and Menta Health Indicators in the United States: Results from the 2016 National Survey on Drug Use and Health.; 2017.

2. Compton WM, Han B, Jones CM, Blanco C, Hughes A. Marijuana use and use disorders in adults in the USA, 2002-14: analysis of annual crosssectional surveys. The Lancet Psychiatry. 2016;3(10):954-64.

3. Univeristy of Washington Addictions, Drug and Alcohol institute. Learn about marijuana. http://learnaboutmarijuanawa.org/factsheets/whati scannabis.htm. Accessed 20 Apr 2020.

4. Meehan-Atrash J, Korzun T, Ziegler A. Cannabis inhalation and voice disorders: a systematic review. JAMA Otolaryngol Neck Surg. 2019;145(10):956-64. https://doi.org/10.1001/jamaoto.2019.1986.

5. Health Canada. Side Effect Reporting Form. (April 2018) https://www. canada.ca/en/health-canada/services/drugs-health-products/medef fect-canada/adverse-reaction-reporting/consumer-side-effect-reportingform.html. Accessed 26 June 2021

6. Leherny S. 'Adverse Effect,'Not the Same as 'Side Effect' in Pharmacy Times. (Februrary 22, 2017). https://www.pharmacytimes.com/view/ adverse-event-not-the-same-as-side-effect. Accessed 27 June 2021

7. Volkow ND, Baler RD, Compton WM, Weiss SR. Adverse health effects of marijuana use. N Engl J Med. 2014;370(23):2219-27. https://doi.org/10. 1056/NEJMra1402309.

8. Health Canada. Report a side effect. (December 14, 2020) https://www. canada.ca/en/health-canada/services/drugs-health-products/medeffectcanada/adverse-reaction-reporting.html. Accessed 26 June 2021.

9. Valentino WL, Mckinnon BJ. What is the evidence for cannabis use in otolaryngology ?: A narrative review. Am J Otolaryngol. 2019;40(5):770-5. https://doi.org/10.1016/j.amjoto.2019.05.025.

10. de Carvalho MFF, Dourado MR, Fernandes IB, Araújo CTP, Mesquita AT, Ramos-jorge ML. Head and neck cancer among marijuana users: A meta-analysis of matched case-control studies. Arch Oral Biol. 2015;60(12):1750-5.

11. Tricco AC, Lillie E, Zarin W, et al. PRISMA Extension for Scoping Reviews (PRISMA-SCR): Checklist and Explanation. Ann Intern Med. 2018;169(7):467-73. https://doi.org/10.7326/m18-0850.

12. Howick J, Chalmers I, Glaszious P, et al. The Oxford 2011 Levels of Evidence. Oxford Cent Evidence-Based Med. 2011. https://www.cebm.net/ wp-content/uploads/2014/06/CEBM-Levels-of-Evidence-2.1.pdf.

13. Campbell S, Kung J. Filter to Retrieve Studies Related to Cannabis in the OVID MEDLINE Database. John W. Scott Health Sciences Library, University of Alberta.

14. Sterne JAC, Hernán MA, Reeves BC, et al. ROBINS-I: a tool for assessing risk of bias in non-randomised studies of interventions. BMJ. 2016. https://doi. org/10.1136/bmj.i4919.

15. Higgins JPT, Altman DG, Gøtzsche PC, et al. The cochrane collaboration's tool for assessing risk of bias in randomised trials. BMJ. 2011. https://doi. org/10.1136/bmj.d5928.

16. Ahrens A, Bressi T. Should Marijuana Be Considered a Risk Factor for Oral Cancer? A Significant Case Report. Addict Disord Their Treat. 2005:4(2):77-80

17. Ahrens A, Bressi T. Marijuana as Promoter for Oral Cancer? More Than a Suspect. Addict Disord Their Treat. 2007:6(3):117-9.

18. Aldington S, Harwood M, Cox B, et al. Cannabis use and cancer of the head and neck: case-control study. Otolaryngol Neck Surg. 2008;138(3):374-80. https://doi.org/10.1016/j.otohns.2007.12.002.

19. Berthiller J, Lee YA, Boffetta P, et al. Marijuana smoking and the risk of head and neck cancer: pooled analysis in the INHANCE Consortium. Cancer Epidemiol Biomarkers Prev. 2009;18(5):1544-51. https://doi.org/ 10.1158/1055-9965.EPI-08-0845.Marijuana.

20. Bhattacharyya S, Mandal S, Banerjee S, Kumar Mandal G, Kumar Bhowmick A, Murmu N. Cannabis smoke can be a major risk factor for earlyage laryngeal cancer-a molecular signaling-based approach. Tumor Biol. 2015:36(8):6029-36. https://doi.org/10.1007/s13277-015-3279-4.

21. Bonnet U. Chronic cannabis abuse, delta-9- tetrahydrocannabinol and thyroid function. Pharmacopsychiatry. 2013:46(1):35-6.

22. Brumbach S, Goodman SS, Baiduc RR. Behavioral hearing thresholds and distortion product otoacoustic emissions in cannabis smokers. J Speech Lang Hear Res. 2019;62(9):3500-16.
23. Carley DW, Prasad B, Reid KJ, et al. Pharmacotherapy of apnea by cannabimimetic enhancement, the PACE clinical trial: effects of dronabinol in obstructive sleep apnea. Sleep. 2018:41(1):1-13.

24. Cook RL, Thompson EL, Kelso NE, et al. Sexual behaviors and other risk factors for oral human papillomavirus infections in young women. Sex Transm Dis. 2014;41(8):486-92. https://doi.org/10.1097/OLQ.0000000000 000159.Sexual.

25. Darling M, Arendorf T. Effects of cannabis smoking on oral soft tissues. Community Dent Oral Epidemiol. 1993;21(2):78-81.

26. Darling M, Learmonth $\mathrm{G}$, Arendorf T. Oral cytology in cannabis smokers. J South African Dent Assoc. 2002;57(4):132-5.

27. Darling M, ArendorfT, Coldrey N. Effect of cannabis use on oral candidal carriage. J Oral Pathol Med. 1990;19(11):319-22.

28. Donald PJ. Marijuana smoking-possible cause of head and neck carcinoma in young patients. Otolaryngol Neck Surg. 1986;94(4):517-21.

29. Feng B-J, Khyatti M, Dahmoul S, et al. Cannabis, tobacco and domestic fumes intake are associated with nasopharyngeal carcinoma in North Africa. Br J Cancer. 2009;101(7):1207-12. https://doi.org/10.1038/sj.bjc 6605281

30. Gillison ML, Souza GD, Westra W, et al. Distinct Risk Factor Profiles for Human Papillomavirus Type 16 - Positive and Human Papillomavirus Type 16 - Negative Head and Neck Cancers. J Natl Cancer Inst. 2008;100(6):407-20. https://doi.org/10.1093/jnci/djn025.

31. Han B, Gfroerer JC, Colliver JD. Associations between duration of illicit drug use and health conditions : results from the 2005-2007 national surveys on drug use and health. Ann Epidemiol. 2010;20(4):289-97. https:// doi.org/10.1016/j.annepidem.2010.01.003.

32. Hashibe M, Morgenstern $\mathrm{H}, \mathrm{Cui} Y$, et al. Marijuana use and the risk of lung and upper aerodigestive tract cancers : results of a population-based case-control study. Cancer Epidemiol Biomarkers Prev. 2006;15(10):182935. https://doi.org/10.1158/1055-9965.EPI-06-0330.

33. Henderson RL, Tennant FS, Guerry R, Germany W. Respiratory manifestations of hashish smoking. Arch Otolaryngol Neck Surg. 1972;95(3):248-51.

34. Herning Rl, Better W, Cadet JL. EEG of Chronic marijuana users during abstinence: relationship to years of marijuana use, cerebral blood flow and thyroid function. Clin Neurophysiol. 2008;119(2):321-31.

35. Hess CB, Rash DL, Daly ME, Farwell DG, Bishop J, Vaughan AT. Competing causes of death and medical comorbidities among patients with human papillomavirus-positive vs human papillomavirus-negative oropharyngeal carcinoma and impact on adherence to radiotherapy. AMA Otolaryngol Neck Surg. 2014;140(4):312-6. https://doi.org/10.1001/ jamaoto.2013.6732.

36. Kagen SL, Kurup VP, Sohnle PG, Fink JN. Marijuana smoking and fungal sensitization. J Allergy Clin Immunol. 1983:71(4):389-93.

37. Liang C, Mcclean MD, Marsit C, Christensen B, Nelson HH, Kelsey KT. A population-based case-control study of marijuana use and head and neck squamous cell carcinoma. Cancer Prev Res. 2009;2(8):759-68. https://doi.org/10.1158/1940-6207.CAPR-09-0048.A.

38. Liedgren S, Odkvist LM, Davis E, Fredrickson J. Effect of marihuana on hearing. J Otolaryngol. 1975;5(3):233-7.

39. Llewellyn CD, Linklater K, Bell J, Johnson NW, Warnakulasuriya S. An analysis of risk factors for oral cancer in young people : a case-control study. Oral Oncol. 2004;40(3):304-13. https://doi.org/10.1016/j.oraloncolo gy.2003.08.015.

40. Llewellyn CD, Johnson NW, Warnakulasuriya KAAS. Risk factors for oral cancer in newly diagnosed patients aged 45 years and younger: a casecontrol study in Southern England. J Oral Pathol Med. 2004;33(9):525-32.

41. Malhotra S, Heptulla RA, Homel P, Motaghedi R. Effect of marijuana use on thyroid function and autoimmunity. Thyroid. 2017;27(2):167-73. https://doi.org/10.1089/thy.2016.0197.

42. Marks MA, Chaturvedi AK, Kelsey K, et al. Association of marijuana smoking with oropharyngeal and oral tongue cancers: pooled analysis from the INHANCE consortium. Cancer Epidemiol Biomarkers Prev. 2013:23(1):160-72. https://doi.org/10.1158/1055-9965.EPI-13-0181.

43. Mueller PB, Wilcox JC. Effect of marijuana smoking on vocal pitch and quality. Ear Nose Throat J. 1980:59(12):506-9.

44. Mulheran M, Middleton P, Henry J. The acute effects of tetrahydrocannabinol on auditory threshold and frequency resolution in human subjects. Hum Exp Toxicol. 2002;21(6):289-92.

45. Muller K, Kazimiroff J, Fatahzadeh M, et al. Oral human papillomavirus infection and oral lesions in HIV-positive and HIV-negative dental 
patients. J Infect Dis. 2015;212(5):760-8. https://doi.org/10.1093/infdis/ jiv080.

46. Newman TM, Krishnan LP, Lee J, Adami GR. Microbiomic differences at cancer-prone oral mucosa sites with marijuana usage. Sci Rep. 2019;9:18. https://doi.org/10.1038/s41598-019-48768-z.

47. Parshad O, Kumar M, Melville G. Thyroid-gonad relationship in marijuana smokers. A field study in Jamaica. West Indian Med J. 1983;32(2):101-5.

48. Prasad B, Radulovacki MG, Carley DW. Proof of concept trial of dronabinol in obstructive sleep apnea. Front Psychiatry. 2013;4(1):1-5. https://doi. org/10.3389/fpsyt.2013.00001.

49. Rosenblatt KA, Daling JR, Chen C, Sherman KJ, Schwartz SM. Marijuana Use and Risk of Oral Squamous Cell Carcinoma. Cancer Res. 2004;64(11):4049-54.

50. Shah FJ, Lala S, Saba R, Gul S, Saba R. Association of life style factors in patients having head and neck carcinomas visiting dental hospitals. Pak J Med Heal Sci. 2018;12(4):1676-8.

51. Spector M. Acute vestibular effects of marijuana. J Clin Pharmacol. 1973;13(5):214-7.

52. Spector M. Chronic vestibular and auditory effects of marijuana. Laryngoscope. 1974:84(5):816-20

53. Stokes JR, Hartel R, Ford LB, Casale TB. Cannabis (hemp) positive skin tests and respiratory symptoms. Ann Allergy, Asthma Immunol. 2000;85(3):238-40.

54. Tashkin DP, Simmons MS, Tseng C. Impact of changes in regular use of marijuana and/or tobacco on chronic bronchitis. COPD J Chronic Obstr Pulm Dis. 2012;9(4):367-74. https://doi.org/10.3109/15412555.2012. 671868.

55. Taylor FM III. Marijuana as a potential respiratory tract carcinogen: a retrospective analysis of a community hospital population. South Med J. 1988;81(10):1213-6.

56. Tennant F, Preble M, Prendergast T, Ventry P. Medical manifestations associated with hashish. J Am Med Assoc. 1971;216(12):1965-9.

57. Weich TM, Tochetto TM, Seligman L. Brain stem evoked response audiometry of former drug users. Braz J Otorhinolaryngol. 2012;78(5):90-6. https://doi.org/10.5935/1808-8694.20120014.

58. Winton-Brown TT, Allen P, Bhattacharrya S, et al. Modulation of auditory and visual processing by delta-9-tetrahydrocannabinol and cannabidiol: an fMRI Study. Neuropsychopharmacology. 2011;36(7):1340-8. https:// doi.org/10.1038/npp.2011.17.
59. Xie M, Gupta MK, Archibald SD, Jackson BS, Edward J, Young M. Marijuana and head and neck cancer: an epidemiological review. J Otolaryngol Head Neck Surg. 2018;47(1):1-7.

60. Zhang Z-F, Morgenstern H, Spitz MR, et al. Marijuana use and increased risk of squamous cell carcinoma of the head and neck. Cancer Epidemiol Biomarkers Prev. 1999;8(12):1071-8.

61. Zhang Z, Morgenstern H, Spitz MR, et al. Environmental tobacco smoking, mutagen sensitivity, and head and neck squamous cell carcinoma. Cancer Epidemiol Biomarkers Prev. 2000;9(10):1043-9.

62. Zhang $H$, Xie M, Levin $M$, et al. Survival outcomes of marijuana users in p16 positive oropharynx cancer patients. J Otolaryngol - Head Neck Surg. 2019:48:1-6.

63. Zuskin E, Kanceljak B, Pokrajac D, Schachter EN, Witek T Jr. Respiratory symptoms and lung function in hemp workers. Br J Ind Med. 1990;47(9):627-32.

64. Ramar K, Rosen IM, Kirsch DB, et al. Medical cannabis and the treatment of obstructive sleep apnea: an American Academy of sleep medicine position statement. J Clin sleep Med. 2018;14(4):679-81. https://doi.org/ $10.5664 / \mathrm{jcsm} .7070$.

65. State Medical Marijuana Laws. National Conference of State Legislatures.

66. Data NF. U.S. Cannabis Report: 2019 Industry Outlook.; 2019.

67. Zagorsky JL. How Prohibition changed the way Americans drink, 100 years ago. The Conversation. 2020

68. Haughwout SP, Slater ME. Apparent per capita alcohol consumption: national, state, and regional trends, 1977-2016.; 2018.

69. Abramovici H, Lamour S, Mammen G. Information for health care professionals: cannabis (marihuana, marijuana) and the cannabinoids. Onoway: Health Canada; 2018.

70. National Academies of Sciences, Engineering and $M$. The health effects of cannabis and cannabinoids: the current state of evidence and recommendations for research. Washington, DC: The National Academies Press: 2017. https://doi.org/10.17226/24625

\section{Publisher's Note}

Springer Nature remains neutral with regard to jurisdictional claims in published maps and institutional affiliations. 